Eastern Europe since 1945 


\section{The Making of the Modern World}

Series Editor: GEOFFREY WARNER

Published:

Eastern Europe since 1945

Geoffrey Swain and Nigel Swain

Forthcoming:

Germany since 1945

Mark Roseman

France since 1945

John Simmonds and Hilary Footitt 


\section{Eastern Europe since 1945}

Geoffrey Swain and Nigel Swain 
ISBN 978-0-333-54544-7 ISBN 978-1-349-22656-6 (eBook)

DOI 10.1007/978-1-349-22656-6

(C) Geoffrey Swain and Nigel Swain 1993

Reprint of the original edition 1993

All rights reserved. No reproduction, copy or transmission of this publication may be made without written permission.

No paragraph of this publication may be reproduced, copied or transmitted save with written permission or in accordance with the provisions of the Copyright, Designs and Patents Act 1988, or under the terms of any licence permitting limited copying issued by the Copyright Licensing Agency, 90 Tottenham Court Road, London W1P 9HE.

Any person who does any unauthorised act in relation to this publication may be liable to criminal prosecution and civil claims for damages.

First published 1993 by

MACMILLAN PRESS LTD

Houndmills, Basingstoke, Hampshire RG21 6XS

and London

Companies and representatives

throughout the world

ISBN 978-0-333-54543-0 hardcover ISBN 978-0-333-54544-7 paperback

A catalogue record for this book is available from the British Library.

$\begin{array}{llllllll}11 & 10 & 9 & 8 & 7 & 6 & 5 & 4\end{array}$

$\begin{array}{llllllll}03 & 02 & 01 & 00 & 99 & 98 & 97 & 96\end{array}$ 
To our parents 
I believed in communism. For me, communism was freedom. That was my mistake. Absolute freedom doesn't exist, especially not in communism, but if I hadn't believed this I wouldn't have become a communist. Of course the quest for such freedom leads to revolution, violence, overthrowing the ruling classes, the long transformation of society by education. But I was convinced that in the end this process was moving towards more and more freedom, no end to this freedom.

Milovan Djilas, January 1992 


\section{Contents}

List of Tables viii

$\begin{array}{ll}\text { Chronology } & \text { ix }\end{array}$

Introduction 1

1 Revolution in Eastern Europe 12

2 Different Roads to Socialism 33

3 An End to Diversity $\quad 56$

4 1956: Communism Renewed? 77

5 Actually Existing Socialism in Operation 101

6 Reform Communism or Economic Reform 127

7 Neo-Stalinism Triumphant 159

8 The Fall of Actually Existing Socialism 189

$\begin{array}{ll}\text { Conclusion } & 223\end{array}$

$\begin{array}{ll}\text { Notes } & 227\end{array}$

$\begin{array}{ll}\text { Index } & 244\end{array}$ 


\section{List of Tables}

5.1 The Creation of the Soviet-type Planning System in Eastern Europe

5.2 Land reform and collectivisation in post-war Eastern Europe

5.3 Socialised share of industrial output and retail turnover in 1952

5.4 Share of net material product devoted to accumulation (net investment in fixed capital plus increases in inventories) and personal consumption, in per cent

5.5 Share of investment by branch 1953-5 (Comecon countries gross investment, Yugoslavia net investment in fixed assets)

5.6 Index of Gross Domestic Product and Energy Intensity of Gross Domestic Product, 1973 (United States $=100$ )

5.7 Constitutional arrangements in Eastern Europe 116-17

5.8 Minor political parties in Eastern Europe

5.9 Full name of Communist Party and Party Leader's non-Party post (1980-1)

6.1 National income 1956-65 (\% annual rates of growth of net material product) 


\section{Chronology}

1 April 1939

23 August 1939

3 September 1939

22 June 1941

May 1943

June 1944

July 1944

23 August 1944

end August 1944

5 September 1944

9 September 1944

1 October 1944

November 1944

December 1944

5 January 1945

February 1945

end February 1945

March 1945

April 1945

8 May 1945

August 1945

4 November 1945

11 November 1945

18 November 1945

2 December 1945
Final defeat of the Republican Government during the Spanish Civil War

Nazi-Soviet Pact: East European Communist Parties adopt new revolutionary programme

Start of Second World War

Nazis invade Soviet Union: Balkan Communist Parties start insurrections

Dissolution of the Comintern

British Government recognises Tito's Communist Government

Red Army crosses into Poland: National Liberation Committee established

King Michael's coup in Romania: formation of coalition government

Stalin's decision to support Bulgarian insurrection

Soviet Union declares war on Bulgaria

Communist coup in Bulgaria

Red Army crosses into Hungary

Start of civil war in Poland lasting until summer 1945

British suppress communist insurrection in Greece

Stalin recognises Communist government in Poland Yalta Conference: decision to form National Unity Government in Poland

Stalin supports Communist coup in Romania

Stalin shelves plans for Balkan Federation after Allied protests

Liberation of Czechoslovakia

End of Second World War

Potsdam Conference: agreement on conditions for signing peace treaties with Hungary, Bulgaria and Romania

Hungarian elections

Yugoslav elections

Bulgarian elections (boycotted by opposition candidates)

Albanian elections 
26 May 1946

30 June 1946

27 October 1946

19 November 1946

19 January 1947

February 1947

March 1947

May 1947

June 1947

10 July 1947

30 August 1947

end September 1947 Foundation of Cominform

27 November 1947 New revolutionary stance adopted by Czechoslovak communists

December 1947

end February 1948

1 March 1948

July 1948

May 1949

September 1949

November 1949

December 1949

June 1950

November 1952

6 March 1953

15 June 1953

end June 1953

16 January 1954

Elections in Czechoslovakia

Polish referendum

Bulgarian elections in which opposition takes part

Romanian elections

Polish elections

Truman doctrine; American commitment to anticommunist cause in Greece

Stalin's support for Yugoslavia's role in Greece

Communists excluded from government in France and Italy

Marshall Plan announced

Stalin instructs Czechoslovak government to reject Marshall Aid

Hungarian elections

Diplomatic offensive launched by Yugoslavia

Increased aid for Greek communists

Communist coup in Czechoslovakia

Start of Stalin-Tito dispute

Yugoslavs decide to resist Stalin's demand that they join a Balkan Federation dominated by Bulgaria and Albania

Yugoslavia expelled from the Cominform

Cominform countries adopt 'soviet' model of industrial planning and collectivised agriculture

Trial of Koçi Xoxe

Trial of László Rajk

Cominform denounces Yugoslav regime: diplomatic relations broken off

Trial of Traicho Kostov

Yugoslavs establish workers' self management

Trial of Rudolf Slánský

Yugoslav Communist Party renamed League of Communists

Death of Stalin

Restoration of diplomatic relations between Soviet Union and Yugoslavia

Brioni plenum of Yugoslav Party ends reform programme

New Hungarian Prime Minister Imre Nagy introduces 'new course'

Milovan Djilas disciplined for writing that the Leninist Party was obsolete 
23 October 1954

February 1955

March 1955

26 May 1955

February 1956

April 1956

18 April 1956

20 June 1955

end June 1956

18 July 1956

19 September 1956

19 October 1956

23 October 1956

24 October 1956

30 October 1956

2 November 1956

4 November 1956

15 November 1956

November 1957

April 1958

May 1958

Late 1958

January 1959

April 1961

13 August 1961

October 1961
Patriotic People's Front founded in Hungary

Khrushchev replaces Malenkov in Soviet Union

Nagy deposed in Hungary

Khrushchev's rapprochement with Tito: inter-state relations restored

Khrushchev denounces Stalin at XXth Party Congress

New leadership in Poland and other East European states

Cominform abolished

Khrushchev's rapprochement with Tito: party relations restored

Riots in Poznan

Rákosi dismissed at Soviet request

Poles cautioned not to relax discipline

Start of over three weeks of talks between Khrushchev and Tito

Polish Party Plenum restores Gomułka to leadership: mobilised working class frustrates plans for Soviet armed intervention

Demonstrations mark start of Hungarian revolution

Soviet troops intervene in Hungary

Nagy forms multi-party government: the next day opens talks seeking the withdrawal of Hungary from the Warsaw Pact

Khrushchev and Tito agree to intervene in Hungary

Soviet intervention resumes

Soviet-Polish agreement on the stationing of Soviet troops in Poland

Conference of Ruling Communist Parties fails to restore unity to communist movement

Yugoslav League of Communists adopts a programme asserting its unique road to socialism

Meeting of the Political Consultative Committee of the Warsaw Pact

Announcement that Soviet troops will withdraw from Romania

Renewed collectivisation drive

XXIst Congress of the Soviet Party

New emphasis on economic development and catching up with the West

Soviet Union cancels aid to Albania

Building of Berlin Wall

XXIInd Congress of the Soviet Party

Second de-Stalinisation campaign 
August 1962

Early 1963

July 1963

September 1963

July 1964

October 1964

July 1965

July 1966

March 1968

January 1968

June 1968

20-1 August 1968

1970-1

December 1970

May 1971

September 1971

November 1972

December 1972

August 1975

June 1976

September 1976

January 1977

July 1978

July 1980

August 1980

13 December 1980

March-April 1981

1982

July 1983

March 1985

October 1987
Beginnings of Sino-Soviet split

Kádár: 'Those who are not against us are with us' in Hungary

'Revolt of the intellectuals' in Czechoslovakia

Plans for a greater degree of Comecon integration abandoned because of Romanian opposition

GDR decides to implement the New Economic System throughout the economy

Hungarian Central Committee accepts the principles of the New Economic Mechanism

Khrushchev replaced by Brezhnev

Yugoslavia's second economic reform

Reformists secure the dismissal of Ranković in Yugoslavia

Student demonstrations in Poland

Dubček replaces Novotny as Czechoslovak Party leader

Student demonstrations in Yugoslavia

Soviet invasion of Czechoslovakia

Croat nationalist unrest in Yugoslavia

Price increases in Poland lead to 'Baltic Crisis'

Honecker replaces Ulbricht in GDR

Four Power Agreement on Berlin

Measures partially recentralising the economy approved by Central Committee in Hungary

Basic Treaty between GDR and German Federal Republic

Helsinki Final Act

Price increases in Poland result in strikes and demonstrations

Foundation in Poland of the Committee for the Defence of Workers (KOR)

Foundation of Charter 77 in Czechoslovakia

China suspends foreign aid to Albania

Price increases in Poland

Solidarity free trade union founded in Poland

Martial law declared in Poland

Ethnic disturbances in Kosovo

Debt crisis in Yugoslavia. 'Small business reform' in Hungary

Martial law lifted in Poland

Gorbachev becomes General Secretary of Central Committee of CPSU

Slobodan Milošević becomes leader of Serbian League of Communists 
August 1988

June 1989

August 1989

September 1989

9 November 1989

November 1989

December 1989

21 December 1989

25 December 1989 January 1990

March-April 1990

April 1990

April-May 1990

May 1990

June 1990

1 July 1990

3 October 1990

November-

December 1990

December 1990January 1991 April 1991
Polish government decides to negotiate with Solidarity

Elections in Poland. Solidarity wins vast majority of seats available to it

Solidarity-led government formed in Poland

Hungary allows GDR citizens to emigrate via Austria. Government and Opposition Round Table Talks concluded

Berlin Wall breached

Demonstrations in Prague. Zhivkov resigns in Bulgaria

Government of National Understanding formed in Czechoslovakia

Ceauşescu rally disrupted. Fighting between demonstrators and security police

Nicolae and Elena Ceaussescu executed

Poland implements Balcerowicz 'shock therapy' programme

Elections in Hungary. Right of centre coalition government led by Hungarian Democratic Forum

Elections in Slovenia. Won by DEMOS coalition

Elections in Croatia won by nationalistic Croatian Democratic Union

Elections in Romania. Won by National Salvation Front which is dominated by former communists

Elections in Czechoslovakia. Won by Civic Forum and Public Against Violence

Elections in Bulgaria. Won by the former communist party

Miners break up opposition demonstration in Romania

German currency union

Germany reunified

Presidential elections in Poland. Wałesa elected

Communist-led government in Bulgaria resigns following strike wave

Elections in Macedonia, Bosnia Hercegovina, Serbia and Montenegro. Former communists win in Serbia and Montenegro. Weak coalition government in Bosnia and Hercegovina. Nationalist coalition in Macedonia

Anti-government demonstrations in Albania Elections in Albania. Won by former communists 
June 1991

28 June 1991

1 July 1991

June-July 1991

September 1991

October 1991

December 1991

26 December 1991

15 January 1992
Albanian communist-led government resigns after strike-wave

Comecon formally dissolved

Warsaw Pact formally dissolved

Slovenia established de facto independence after brief hostilities

Relations between Croatia and Serbia degenerate to protracted civil war

Romanian government resigns after demonstrations led by miners. Broad-based interim government formed

Elections in Poland. No clear winner. Elections in Bulgaria. Won by Union of Democratic Forces with small majority

Albanian Democratic Party withdraws support from coalition government

Soviet Union formally dissolved, following Gorbachev's resignation on Christmas Day

The European Community recognises the independence of Slovenia and Croatia and hence the break-up of Yugoslavia 